\title{
The Level of Some Energy Metabolism Indices in Forest and Field Populations of Roe Deer ${ }^{1}$
}

\author{
Barbara MAJEWSKA, Zygmunt PIELOWSKI \& Lesław ŁABUDZKI
}

Majewska B., Pielowski Z. \& Łabudzki L., 1982: The level of some energy metabolism indices in forest and field populations of roe deer. Acta theriol., 27, 32: 471-477 [With 2 Tables]

Contents of glycogen, ATP, ADP, total lipids, alkaline phosphatase activity and $a$-amylase were determined in some tissues of roe deer belonging to a field and a forest population. Analysis revealed a higher concentration of hepatic and muscular glycogen, lower contents of hepatic high-energy phosphates, higher level of plasma total lipids and higher alkaline phosphatase activity in the plasma of the field population of roe deer, whereas there was higher amylolytic activity of the blood plasma in the forest population. This points to the slightly different course of certain biochemical processes in individuals of ecologically differentiated populations inhabiting two different habitats.

[Inst. Animal Physiol., Warsaw Agric. Univ. Nowoursynowska 166, 02-766 Warszawa (BM); Dept. Wildl. Manage., Agric. Acad., Al. Wojska Polskiego 71c, 60-628 Poznań (LŁ); Polish Hunting Association, Research Station, 62-055 Czempiń (ZP)]

\section{INTRODUCTION}

The extensive seried of studies on the characteristics of two roe deer, Capreolus capreolus (Linnaeus, 1758) populations inhabiting respectively a forest and field habitat, included a search for confirmation of Pielowski's hypothesis (1977) that there are two separate ecological forms of roe deer - "forest" and "field". In the above author's opinion populations of these two ecotypes differ in respect of many characteristics, this being a manifestation of their adaptation to living in different habitats. If this is the case. then there must be perceptible differences in the course of basic physiological processes and the values of biochemical indices.

The purpose of the present study was to analyze the levels of hepatic and skeletat muscular glycogen and hepatic and muscular ATP + ADP, plasma total lipids content and activity of the enzymes - alkaline phosphatase and $\alpha$-amylase in roe deer belonging to a forest and a field population. The above indices were chosen owing to the differences in the way of life of such roe deer depending on the habitat in which they live, their different degree of locomotor activity and also the kind and quality of the food they consume (Kałuziński, 1982a).

${ }^{1}$ Praca wykonana w ramach problemu MR-II/15 koordynowanego przez Instytut Ekologii PAN. 


\section{MATERIAL AND METHODS}

The forest roe deer population came for the Wildlife Management Experimental Station, Agricultural Academy of Poznań, at Zielonka, about 8,000 ha in extent; situated about $20 \mathrm{~km}$ to the north of Poznan. The field population of roe deer came from the Czempin range of 15,000 ha, situated $30 \mathrm{~km}$ to the south of Poznan. Both ranges represent typical roe deer habitats and the roe deer populations living there are characterized by all the different ecological features of forest or field roe deer (Fruzinski et al., 1982; Kałuziński, 1982b).

The roe deer taken for our studies were shot during the period from May 1977 to January 1979. On account of the close season for this game bucks were shot in May and August, and does in October and January. The following 3 age classes were distinguished: I - juvenile, individuals $1-2$ years old, II adolescent individuals, 2-3 years old, III - adult individuals over 3 years old. The number of animals examined is given in table 1 .

Table 1

Number of roe deer examined in each age class.

\begin{tabular}{lccc}
\hline \multirow{2}{*}{ Roe deer population } & \multicolumn{3}{c}{ Age class } \\
\cline { 2 - 4 } & I & II & III \\
\hline Forest (Zielonka) & 5 & $7-16$ & $5-15$ \\
Field (Czempiń) & 4 & $12-27^{1}$ & $19-26^{1}$ \\
\hline
\end{tabular}

1 Depending on index studied.

Samples from the following tissues were taken for the studies:

1. plasma - obtained from blood taken for heparine from the pleural cavity immediately after killing the ainmal.

2. duodeum - parts cooled at a temperature of $+4^{\circ} \mathrm{C}$, after sampling.

3. Iiver - parts cooled, after sampling, at a temperature of $+4^{\circ} \mathrm{C}$, from which homogenates were obtained in a $\mathrm{NaCl}$ physiological solution.

4. liver - parts frozen immediately after sampling and weighing at dry ice temperature $\left(-78.5^{\circ} \mathrm{C}\right)$.

5. muscles - parts from the scapular muscle frozen after previously weighing at dry ice temperature.

The following determinations were made for the above tissues:

1. plasma total lipids by the Hankiewicz \& Szczęśniak (1971) method.

2. glycogen content of the skeletal muscles and liver by the Good, Kramer \& Somogyi (1933) method, in the form of glucose obtained after its acid hydrolysis and determined by the Nelson-Somogyi method as modified by KingGarner (King, 1946).

3. ATP contents together with ADP in the skeletal muscles and liver in the form of inorganic phosphorus liberated after hydrolysis of these nucleotides by the Umbreit et al. method (1957).

4. total protein in supernatants of homogenates of the liver, and mucous membrane of the duodenum and liver, using the Gleiss and Hinsberg burette method (1951) in order to obtain the specific activities of the enzymes examined.

5. alkaline phosphatase activity of plasma and homogenates of the duodenal and hepatic mucous membrane by the Bessey, Lowry \& Brook method (1946) 
6. $\alpha$-amylase activity of plasma and of duodenal and hepatic mucous membrane homogenates by the van Loon method, as modified by Caraway (van Loon et al. 1952).

For technical reasons it was not possible to obtain, with the number of roe deer and amount of time available, a large enough amount of material to permit of additionally analyzing seasonal variation in the parameters examined.

Statistical calculations of results were made, finding the so-called "smallest proved difference" $(N I R=t: S r)$ where $t$ is a value of Student test by the level of significance $=0.05$ and $S r$ is an error of mean difference.

\section{RESULTS}

The level of indices of energy metabolism in individuals of the two ecological forms of roe deer compared proved to vary considerably. In

Table 2

Values of some biochemical indices of "forest" and "field" roe deer.

\begin{tabular}{|c|c|c|c|c|c|c|}
\hline \multirow{2}{*}{ Index } & \multirow{2}{*}{$\begin{array}{l}\text { Age } \\
\text { class }\end{array}$} & \multicolumn{2}{|r|}{ Forest } & \multicolumn{2}{|r|}{ Field } & \multirow{2}{*}{$\begin{array}{l}\text { Significan- } \\
\text { ce of dif- } \\
\text { ferences }\end{array}$} \\
\hline & & $\mathrm{n}$ & $\overline{\mathrm{x}} \pm \mathrm{S} \overline{\mathrm{x}}$ & $\mathrm{n}$ & $\overline{\mathrm{x}} \pm \mathrm{S} \overline{\mathrm{x}}$ & \\
\hline $\begin{array}{l}\text { Glycogen content } \\
\text { in liver } \\
\mathrm{mg} / \mathrm{g} \text { of tissue }\end{array}$ & $\begin{array}{r}\text { I } \\
\text { III }\end{array}$ & $\begin{array}{r}4 \\
15 \\
8\end{array}$ & $\begin{array}{l}2.74 \pm 1.67 \\
4.36 \pm 1.14 \\
4.28 \pm 1.57 \\
\end{array}$ & $\begin{array}{r}4 \\
15 \\
21 \\
\end{array}$ & $\begin{array}{r}4.14 \pm 1.87 \\
12.19 \pm 3.24 \\
12.10 \pm 2.24 \\
\end{array}$ & $\begin{array}{r}\text { N.S. } \\
7.05 \\
7.83\end{array}$ \\
\hline $\begin{array}{l}\text { Glycogen content } \\
\text { in muscles } \\
\mathrm{mg} / \mathrm{g} \text { of tissue }\end{array}$ & $\begin{array}{r}\text { I } \\
\text { III } \\
\end{array}$ & $\begin{array}{r}3 \\
15 \\
12 \\
\end{array}$ & $\begin{array}{l}5.25 \pm 1.37 \\
5.04 \pm 0.71 \\
4.85 \pm 0.58 \\
\end{array}$ & $\begin{array}{r}4 \\
16 \\
23 \\
\end{array}$ & $\begin{array}{l}6.79 \pm 2.44 \\
7.75 \pm 1.00 \\
8.03 \pm 0.97 \\
\end{array}$ & $\begin{array}{r}\text { N.S. } \\
2.55 \\
2.89 \\
\end{array}$ \\
\hline $\begin{array}{l}\text { ATP }+ \text { ADP content } \\
\text { in liver } \\
\mu \mathrm{gP} / \mathrm{g} \text { of tissue }\end{array}$ & $\begin{array}{r}\text { I } \\
\text { II } \\
\text { III }\end{array}$ & $\begin{array}{r}4 \\
11 \\
9 \\
\end{array}$ & $\begin{array}{r}84.4 \pm 50.3 \\
126.7 \pm 16.2 \\
114.5 \pm 15.6 \\
\end{array}$ & $\begin{array}{r}4 \\
19 \\
21 \\
\end{array}$ & $\begin{array}{l}40.7 \pm 15.9 \\
33.9 \pm 6.4 \\
34.9 \pm 5.0 \\
\end{array}$ & $\begin{array}{l}\text { N.S. } \\
30.34 \\
25.83 \\
\end{array}$ \\
\hline $\begin{array}{l}\text { ATP + ADP content } \\
\text { in muscles } \\
\mu \mathrm{gP} / \mathrm{g} \text { of tissue }\end{array}$ & $\begin{array}{r}\text { I } \\
\text { II } \\
\text { III }\end{array}$ & $\begin{array}{r}5 \\
15 \\
15 \\
\end{array}$ & $\begin{array}{l}240.0 \pm 11.7 \\
258.0 \pm 44.2 \\
241.5 \pm 56.0 \\
\end{array}$ & $\begin{array}{r}4 \\
19 \\
26 \\
\end{array}$ & $\begin{array}{l}175.0 \pm 48.9 \\
170.1 \pm 20.8 \\
159.6 \pm 16.5\end{array}$ & $\begin{array}{l}\text { N.S. } \\
\text { N.S. } \\
\text { N.S. }\end{array}$ \\
\hline $\begin{array}{l}\text { Plasma total lipids } \\
\text { in form of trioleate } \\
\mathrm{mol} / \mathrm{dm}^{3}\end{array}$ & $\begin{array}{r}\text { I } \\
\text { III } \\
\end{array}$ & $\begin{array}{r}2 \\
16 \\
9 \\
\end{array}$ & $\begin{array}{l}0.88 \pm 0.20 \\
1.08 \pm 0.10 \\
1.28 \pm 0.16 \\
\end{array}$ & $\begin{array}{r}3 \\
16 \\
21 \\
\end{array}$ & $\begin{array}{l}1.90 \pm 0.27 \\
1.73 \pm 0.15 \\
1.64 \pm 0.12 \\
\end{array}$ & $\begin{array}{l}\text { N.S. } \\
0.37 \\
\text { N.S. }\end{array}$ \\
\hline $\begin{array}{l}\text { Plasma alkaline } \\
\text { phosphatase activity } \\
\text { I.U/100 } \mathrm{cm}^{3} \\
\end{array}$ & $\begin{array}{r}\text { I } \\
\text { III }\end{array}$ & $\begin{array}{r}3 \\
12 \\
5\end{array}$ & $\begin{array}{l}32.65 \pm 9.50 \\
51.88 \pm 8.10 \\
45.41 \pm 6.40 \\
\end{array}$ & $\begin{array}{r}2 \\
14 \\
24 \\
\end{array}$ & $\begin{array}{l}29.52 \pm 8.04 \\
28.93 \pm 3.70 \\
30.65 \pm 3.80 \\
\end{array}$ & $\begin{array}{l}\text { N.S. } \\
17.35 \\
\text { N.S. }\end{array}$ \\
\hline $\begin{array}{l}\text { Alkaline phosphatase } \\
\text { activity of duodenal } \\
\text { mucous membrane } \\
\text { I.U/g of protein }\end{array}$ & $\begin{array}{r}\text { I } \\
\text { II } \\
\text { III }\end{array}$ & $\begin{array}{l}3 \\
7 \\
7 \\
\end{array}$ & $\begin{array}{l}676 \pm 407 \\
488 \pm 105 \\
628 \pm 141 \\
\end{array}$ & $\begin{array}{r}2 \\
13 \\
19 \\
\end{array}$ & $\begin{array}{r}715 \pm 478 \\
1012 \pm 216 \\
1176 \pm 247 \\
\end{array}$ & $\begin{array}{l}\text { N.S. } \\
\text { N.S. } \\
\text { N.S. }\end{array}$ \\
\hline $\begin{array}{l}\text { Alkaline phosphatase } \\
\text { activity in liver } \\
\text { I.U/g of protein } \\
\end{array}$ & II & $\begin{array}{l}2 \\
8 \\
5 \\
\end{array}$ & $\begin{array}{l}16.9 \pm 1.8 \\
22.9 \pm 2.5 \\
30.0 \pm 5.8 \\
\end{array}$ & $\begin{array}{r}3 \\
27 \\
42 \\
\end{array}$ & $\begin{array}{l}29.3 \pm 8.5 \\
28.9 \pm 4.0 \\
26.3 \pm 1.9\end{array}$ & $\begin{array}{l}\text { N.S. } \\
\text { N.S. } \\
\text { N.S. }\end{array}$ \\
\hline $\begin{array}{l}\alpha \text {-amylase activity } \\
\text { of plasma } \\
\text { I.U/100 } \mathrm{cm}^{3} \\
\end{array}$ & $\begin{array}{r}\text { I } \\
\text { III }\end{array}$ & $\begin{array}{r}3 \\
16 \\
10 \\
\end{array}$ & $\begin{array}{l}226.6 \pm 18.8 \\
210.7 \pm 11.4 \\
216.3 \pm 14.8 \\
\end{array}$ & $\begin{array}{r}3 \\
14 \\
24 \\
\end{array}$ & $\begin{array}{l}156.0 \pm 19.6 \\
114.0 \pm 7.5 \\
120.9 \pm 7.6\end{array}$ & $\begin{array}{l}\text { N.S. } \\
28.9 \\
31.0\end{array}$ \\
\hline $\begin{array}{l}\alpha \text {-amylase activity } \\
\text { of duodenal mucous } \\
\text { membrane } \\
\text { I.U/g of protein }\end{array}$ & $\begin{array}{r}\text { I } \\
\text { II } \\
\text { III }\end{array}$ & $\begin{array}{r}2 \\
12 \\
8\end{array}$ & $\begin{array}{l}4566 \pm 1662 \\
4274 \pm 730 \\
7155 \pm 1013 \\
\end{array}$ & $\begin{array}{r}2 \\
12 \\
19 \\
\end{array}$ & $\begin{array}{l}2536 \pm 261 \\
4218 \pm 864 \\
6515 \pm 901 \\
\end{array}$ & $\begin{array}{l}\text { N.S. } \\
\text { N.S. } \\
\text { N.S. }\end{array}$ \\
\hline $\begin{array}{l}\alpha \text {-amylase activity } \\
\text { of liver } \\
\text { I.U/g of protein }\end{array}$ & $\begin{array}{r}\text { I } \\
\text { III }\end{array}$ & $\begin{array}{r}4 \\
10 \\
5\end{array}$ & $\begin{array}{l}40.0 \pm 1.7 \\
48.1 \pm 5.2 \\
50.1 \pm 11.2\end{array}$ & $\begin{array}{r}3 \\
23 \\
44\end{array}$ & $\begin{array}{l}31.9 \pm 6.6 \\
33.4 \pm 3.6 \\
31.8 \pm 1.8\end{array}$ & $\begin{array}{l}\text { N.S. } \\
13.1 \\
12.9\end{array}$ \\
\hline
\end{tabular}


field roe deer in age classes II and III there is a significantly higher hepatic and muscular glycogen level than in forest roe deer (Table 2). Only differences in age class I are not significant, which may be due to the small number of samples available, although even here the tendency is distinct (Table 2). When analyzing high-energy phosphate content in the form of ATP determined jointly with ADP, the reverse proportions were found from those in the case of glycogen. There was significantly less adenosine triphosphate in the hepatic tissue of animals from the field population than in the liver of forest roe deer. No significant differences were, however found in ATP+ADP contents in the muscular tissue of animals from the two groups, although here also there are considerable differences in levels (Table 2).

In addition to hepatic and muscular glycogen blood lipids are also used as energy-producing material for resynthesis of high-energy phosphates. The total lipids content in the plasma of field roe deer is greater than in forest roe deer, which can be demonstrated statistically only in age class II (Table 2).

Plasma alkaline phosphate activity is higher in field roe deer, and in this case also differences between individuals from the two study populations are significant only in age class II (Table 2). Alkaline phosphate activity fails to exhibit statistically significant differences in the duodenal mucous membrane and hepatic tissue in both populations of roe deer (Table 2). Forest roe deer, on the other hand, are characterized by higher $a$-amylase activity of both plasma and liver (Table 2). Differences are not, however, observed in the activity of this enzyme in the duodenal mucous membrane.

\section{DISCUSSION}

There are no data in the literature available on the level of glycogen, ATP and lipids in roe deer tissues, and the results we obtained can only be compared with the metabolite contents recorded by other authors in sheep (as ruminants probably biochemically closest to the species discussed in this paper) or other mammals. Difference in hepatic glycogen concentration is the result of difference in the rate of glucose linking to glycogen, which is connected with UDPG-pyrophosphorylase activity (Ballard \& Oliver, 1965; Morgan \& Parmeggiani, 1964). There are grounds for concluding that the level of glycogen, high-energy compounds or lipid contents in tissues of roe deer from field and forest populations differing in respect of many characteristics, should also differ. This should be determined by, inter alia, the different locomotor activity generally observed in the field roe deer (Fruziński et al., in praep. 
Pielowski, 1983). The proved high contents of such metabolites as: glycogen and lipids, may provide confirmation of the fact that the given individual is connected with the field biotope. Studies on glycogen in muscles and liver in other animals (Armstrong et al., 1974; Baldwin et al., 1973; Bławacka et al., 1977) revealed differences either in the biosynthesis rate of this carbohydrate or the rate at which it is catabolized in tissue under the influence of variations in locomotor dynamics and duration of movement, that is, by factors which under natural conditions differentiate the two roe deer populations. The level of highenergy phosphates is connected with the glycogen content of the above tissues (Morgan \& Parmeggiani, 1964; Harris et al., 1977). Reduction in ATP level in the liver and muscles of the field ecotype is undoubtedly connected with the increased intensity of biosynthesis of glycogen from its precursors in the muscles and liver of these animals. This is characteristic of muscles functioning more intensively over a shorter period.

The total fat content in plasma is connected with differences in carbohydrate metabolism intensity in the muscular and hepatic tissue of these roe deer. The level of plasma total lipids is very high in the field ecotype of roe deer. Experiments made by Hickson et al. (1977) show that accumulation in plasma of one of the lipid fractions - FFA (Free Fatty Acids) and intensification of their oxidation causes reduction in glycogenolysis processes in the liver and muscles. This is characteristic of muscles capable of intensive but short-lived exercise, as opposed to muscles in which glycogen is rapidly broken down and which are capable of less intensive and rapid function, but longerlasting. This explains the differences in the parameters of energy metabolism examined in the two roe deer populations.

The greater plasma alkaline phosphatase activity in the forest ecotype of roe deer is probably due to intensive phosphorylation in the tissues of these animals, although analysis of this enzyme's activity in liver and intestines did not revealed any significant differences between the study groups. These roe deer populations also differ as regards plasma and hepatic $\alpha$-amylase activity, that is, of the enzyme hydrolyzing polysaccharides. "Forest" deer are characterized by intensified processes of polysaccharide hydrolysis in the liver. This affects the level of plasma $\alpha$-amylase total activity, since this contains chiefly the enzyme of hepatic origin, although intestinal amylase forms a considerable percentage in the total activity of this enzyme in plasma. It is probable that more intensive processes of digestion and assimilation take place in the intestine of "forest" as compared with "field" roe deer, and also intensified processes of polysaccharide hydrolysis in the hepatic tissue.

These studies lead to the conclusion that roe deer of two different 
populations inhabiting forest and field exhibit considerable differences in some biochemical processes - energy metabolism and enzyme activity. This would appear to be the result of adaptation to the different way of life of these mammals in the two habitats.

\section{REFERENCES}

1. Armstrong R. B., Saubert C. W., Sembrowich W. L., Shepherd R. E. \&\& Gollnick P. D., 1974: Glycogen depletion in rat skeletal muscle fibers at different intensities and duration of exercise. Pflügers Arch., 352, 3: 243-256.

2. Baldwin K. M., Reitman J. S., Terjung R. L., Winder W. W. \& Holloszy J. O., 1973: Substrate depletion in different types of muscle and in liver during prolonged running. Am. J. Physiol., 225, 5: 1045-1050.

3. Ballard F. J. \& Oliver I. T., 1965: Carbohydrate metabolism in liver from foetal and neonatal sheep. Biochem. J., 95, 1: 191-200.

4. Bessey O. A., Lowry O. H. \& Brock M. J., 1946: A method for the rapid determination of alkaline phosphatase with five cubic millimeters of serum. J. biol. Chem, 164, 1: 321-329.

5. Bławacka B., Roth Z., Wojciechowska F. \& Karoń H., 1977: Effect of exercise on glycogen level in muscles and liver in rats. Acta Physiol. Pol. 28, 5, 431-440.

6. Fruziński B., Kałuziński J. \& Pielowski Z.: Wpływ sytuacji środowiskowej na funkcjonowanie różnych populacji sarn. (in praep.).

7. Fruziński B., Łabudzki L. \& Wlazełko M., 1983: Habitat, density and spatial structure of roe deer population in forest. Acta theriol., 28.

8. Gleiss J. \& Hinsberg K., 1951: Zur fraktionierten colorimetrischen Bestimmung der Serumproteine in Klinischem Laboratorium. Z, ges. exp. Med. 116, 6: $599-620$.

9. Good C. A., Kramer H. \& Somogyi M., 1933: The determination of glikogen. J. biol. Chem., 100, 2: 485-491.

10. Hankiewicz J. \& Szczęśniak W., 1971: Prosta metoda kolorymetrycznego oznaczania tłuszczów calkowitych w surowicy. Wiad. lek., 24, 20: 1965-1969.

11. Harris R. C., Sahlin K. \& Hultman E., 1977: Phosphagen and lactate contents of $\mathrm{m}$. quadriceps femoris of man after exercise. J. appl. Physiol., 43, 5: 852857.

12. Hickson R. C., Rennie M. J., Conlee R. K., Winder W. W. \& Holloszy J. O., 1977: Effects of increased plasma fatty acids on glycogen utilisation and endurance. J. appl. Physiol., 43, 5: 829-833.

13. Kałuziński J., 1982a: Composition of the food of roe deer living in fields and the effects of their feeding on plant production. Acta theriol., 27: 457-470.

14. Kałuziński J., 1982b: Dynamics and structure of a field roe deer population. Acta theriol., 27: 385-408.

15. King E. J., 1946: Microanalysis in medical biochemistry: 17-22. J. A. Churchill, London.

16. van Loon E. J., Likins M. R. \& Seper A. J., 1952: Photometric method for blood amylase by use of starch-iodine color. Am. J. Clin. Path., 22, 11: $1134-1136$.

17. Morgan H. E \& Parmeggiani A., 1964: Regulation of glycogenolysis in muscle. J. biol. Chem., 239, 8: 2435-2443. 
18. Pielowski Z., 1977: Das Feldreh - Wild der Zukunft in der Agrarlandschaft. Beitr, zur Jagd- und Wildforsch., 10: 193-200.

19. Pielowski Z., 1983: Niektóre aspekty struktury ekologicznej populacji sarny polnej zbadane drogą wizualnego znakowania osobników. In praep.

20. Umbreit W. W., Burris R. H. \& Stauffer J. F., 1957: Manometric techniques: 271. Burgess Pub., Co, Minneapolis.

Accepted, July, 29, 1982.

Barbara MAJEWSKA, Zygmunt PIELOWSKI i Lesław ŁABUDZKI

POZIOM NIEKTORYCH WSKAŹNIKOW PRZEMIAN ENERGETYCZNYCH

U SARN Z POPULACJI LESNEJ I POLNEJ

\section{Streszczenie}

W latach 1977-1979 przeprowadzono badania niektórych przemian energetycznych oraz aktywność wybranych enzymów kilkudziesięciu sztuk sarn różnej płci i różnego wieku (Tabela 1). Badane osobniki należały do dwóch różniących się ekologicznie populacji sarn - leśnej z Łowieckiego Ośrodka Doświadczalnego Zielonka koło Poznania oraz polnej z lowiska Czempiń, również w pobliżu Poznania.

Dokonano analizy poziomu glikogenu oraz ATP + ADP wątroby i mięśni i stwierdzono istotnie różniące się poziomy, wyższe u sarn polnych $12,1-12,2 \mathrm{mg} / \mathrm{g}$ i $7,8-$ $-8,0 \mathrm{mg} / \mathrm{g}$ a niższe $u$ sarn leśnych $4,3-4,4 \mathrm{mg} / \mathrm{g}$ i $4,9-5,0 \mathrm{mg} / \mathrm{g}$. Analiza zawartości fosforanów wysokoenergetycznych (ATP + ADP) wykazała odwrotne proporcje niż w wypadku glikogenu. Istotnie mniej tego czynnika stwierdzono w wątrobie sarn polnych $(33,9-35,0 \mu \mathrm{gP} / \mathrm{g})$; u sarn leśnych jego poziom wyniósł aż $114,5-126,7 \mu \mathrm{gP} / \mathrm{g}$. Zawartość lipidów całkowitych okazała się wyższa w osoczu sarn polnych aniżeli u sarn leśnych odpowiednio $1,64-1,90 \mathrm{~mol} / \mathrm{dm}^{3}$ i $0,88-1,28 \mathrm{~mol} / \mathrm{dm}^{3}$. Także aktywność fosfatazy zasadowej osocza była wyższa u sarn z pól, przy czym w obu wypadkach różnice statystycznie istotne stwierdzono jedynie u osobników $2-3$ letnich. Sarnę leśną natomiast charakteryzuje wyższa aktywność $\alpha$-amylazy tak osocza jak i wątroby (Tabela 2).

W wyniku przeprowadzonych badań stwierdzono, że osobniki dwóch różnych populacji sarn - leśnej i polnej, wykazują znaczne zróżnicowanie niektórych procesów biochemicznych, co wydaje się być rezultatem przystosowań do innego trybu życia, związanego $\mathrm{z}$ odmiennym środowiskiem bytowania. 